\title{
Морфологічні зміни в нирках за умов гострого поширеного перитоніту на тлі цукрового діабету
}

\begin{abstract}
Мета роботи: дослідити морфологічні зміни в нирках піддослідних тварин при змодельованому гострому поширеному перитоніті на тлі цукрового діабету порівняно із тваринами з експериментальним гострим поширеним перитонітом.

Матеріалиіметоди. В експерименті використано 56 білих щурів. Цукровий діабет моделювалишляхом внутрішньоочеревинного введення стрептозотоцину фірми “Sigmal” з розрахунку 7 мг на 100 г маси тварини, гострий поширений перитоніт - введенням 0,5 мл 10 \% профільтрованої калової суспензії в черевну порожнину досліджуваних тварин. Досліджували тканину нирки 1, 3, 7 доби від початку моделювання перитоніту.

Результати досліджень та їх обговорення. У тварин із гострим поширеним перитонітом на тлі цукрового діабету патоморфологічні зміни були більш виражені: судини венозного русла дещо розширювались, були повнокровні, візуалізувались дрібні периваскулярні точкові крововиливи. Більшість вивідних канальців були розширені, проте їх просвіти були вільні від ексудату. В петлях Генле і прямих канальцях ми спостерігали виражений набряк епітелію.

У тварин із гострим поширеним перитонітом на тлі цукрового діабету спостерігалися більш виражені патоморфологічні зміни у тканині нирок у всі терміни спостереження порівняно із групою тварин, яким не моделювали цукровий діабет, що характеризувалися периваскулярним набряком, збільшенням та розширенням судинного просвіту, наявністю серозного ексудату.
\end{abstract}

Ключові слова: гострий поширений перитоніт; цукровий діабет; морфологічні зміни нирки.

Постановка проблеми і аналіз останніх досліджень та публікакцій. Цукровий діабет (ЦД) - актуальна проблема медицини, оскільки є одним із найбільш поширених ендокринних захворювань зі стійкою тенденцією до зростання. Поряд з онкологічними та серцево-судинними захворюваннями ЦД часто є причиною інвалідизації та смертності хворих $[1,2]$. Упродовж останніх десяти років поширення ЦД в Україні зросло в 1,5 раза і складає близько одного мільйона хворих [3].

Відомо, що ЦД - тяжке прогресуюче захворювання, при якому виникає високий ризик розвитку макро- та мікросудинних порушень з гнійнозапальними та некротичними процесами. Але навіть за умов успішного стаціонарного лікування у 50-60 \% осіб із гнійно-запальними ускладненнями м’яких тканин на фоні ЦД упродовж 3-5 років розвиваються мікроангіопатії [4].

Гострий поширений перитоніт (ГПП) дедалі частіше виникає у хворих із супутньою патологіє, результатом чого є зміни механізмів його розвитку, погіршення наслідків лікування i, як наслідок, висока летальність [5]. Часто це є наслідком недостатнього вивчення патогенетичних механізмів, що задіяні при даній патології, зокрема швидко прогресуючої гіпоксії, порушення мікроциркуляції. ГПП та пов’язані з ними ускладнення на тлі супутнього ЦД вимагають розуміння патоморфологічних механізмів, що лежать в основі розвитку поліорганної недостатності, яка є причи- ною смертності людей молодого і працездатного віку [6, 7]. Нирки - це той орган, який одним із перших зазнає змін за даної патології. Супутній ЦД, який ускладнює перебіг ГПП, характеризується розвитком мікроангіопатій у паренхімі нирок із подальшим наростанням хронічної ниркової недостатності. В доступній літературі ми не знайшли повідомлень, які б повною мірою пояснювали патоморфологічні механізми, які лежать в основі розвитку ускладнень гострого поширеного перитоніту на тлі супутнього ЦД. Вирішенню цієї проблеми присвячене наше дослідження.

Метою роботи: дослідити морфологічні зміни в нирках при змодельованому ГПП на тлі ЦД порівняно із тваринами з експериментальним ГПП.

Матеріали і методи. В експерименті використано 56 білих щурів, яких було поділено на три групи: основна група - 24 тварини із змодельованим ГПП на тлі ЦД; друга група - порівняння - 24 тварини із змодельованим перитонітом; третя - контрольна група - 8 інтактних тварин, яких утримували в стандартних умовах віварію. Усі порівнювані групи тварин були репрезентативні за вагою, статтю та віком. Дане експериментальне дослідження проводили із дотриманням загальних правил і положень Європейської Конвенції із захисту хребетних тварин, які використовуються для дослідницьких та інших наукових цілей (Страсбург, 1986), Загальних етичних принципів експериментів на 
тваринах (Київ, 2001) та Закону України “Про захист тварин від жорстокої поведінки” (2006).

Експериментальний ЦД відтворювали шляхом внутрішньоочеревинного застосування стрептозотоцину натщесерце в дозі 60 мг/кг (фірми “Sigmal”, який розчиняли в буферному натрієвоцитратному розчині $\mathrm{pH}$ 4,5). Дослідження вмісту глюкози здійснювали о 9 год за умов вільного доступу експериментальних тварин до їжі та води протягом нічного періоду часу. Впродовж всього періоду спостереження щурам вводили інсулін (0-2 ОД підшкірно два-пять разів на тиждень) [8].

Через 2 тижні з моменту застосування стрептозотоцину у щурів з венозної крові, яку отримували із хвостової вени, визначали вміст глюкози і в подальших дослідженнях спостерігали тільки в тих щурів, у яких вміст глюкози складав більше 300 мг/л. Тваринам контрольної групи натомість стрептозотоцину уводили підшкірно стерильний 0,9 \% розчин натрію.

Вплив ЦД на перебіг ГПП вивчали на моделі, запропонованій В. А. Лазаренком та співавт. [9]. Ця модель за етіологічними чинниками, клінічними проявами і фазністю перебігу подібна до аналогічного процесу в людини. На 14-у добу після уведення стрептозотоцину тваринам основної групи вводили 10 \% профільтрованої калової суспензії в черевну порожнину досліджуваних щурів у дозі 0,5 мл на 100 г маси тіла. Щури порівняльної групи отримували лише підшкірне уведення калової суспензії. Калову суспензію отримували шляхом змішування ізотонічного розчину і калу зі сліпої кишки 2-3 інтактних тварин, потім ії двічі фільтрували через подвійний шар марлі. Одержану суспензію не пізніше ніж через 20 хв після приготування вводили інтактним щурам пункційним способом. Щоб уникнути пошкодження внутрішніх органів при введенні калової суспензії в черевну порожнину, тварин тримали вертикально, каудальним кінцем вгору. Методом пункції вентральної стінки в центрі середньої лінії живота, направляючи кінець голки по черзі у праве і ліве підребер'я, праву та ліву клубові ділянки, вводили однакову кількість калової суспензії.

Контрольну групу склали інтактні тварини, яких утримували у стандартних умовах віварію. Вилучення матеріалу для гістологічного дослідження здійснювалося на 1-шу, 3-ту та 7-му доби після виведення тварин із експерименту шляхом їх декапітації під тіопенталовим наркозом. Шматочки тканини нирки фіксувалися протягом 72 годин у 10 \% розчину формальдегіду, після чого піддавали стандартній гістологічній проводці через спирти, концентрацію яких збільшували, рідину
Нікіфорова (96 \% спирт і діетиловий ефір у співвідношенні 1:1), хлороформ і заливали парафіном. Із приготовлених парафінових блоків готували серійні зрізи товщиною 4-5 мкм.

Для гістологічних досліджень брали тканину нирки. Отримані шматочки органа фіксували у 10 \% нейтральному розчині формаліну і фіксаторі Ліллі, з наступною заливкою у парафін.

Отримані на санному мікротомі зрізи фарбували гематоксиліном та еозином, за Гейденгайном та за Шабадашем. Характер та глибину морфологічних змін визначали за допомогою мікроскопа Olimpus i системи виведення зображень гістологічних препаратів.

Результати досліджень та їх обговорення. Значні морфологічні зміни спостерігали у тканинах нирок тварин з ГПП та ГПП на тлі ЦД. При гістологічному дослідженні тканини нирки тварин з ГПП на 1-шу добу експерименту ми спостерігали, що кірковий шар нирки був представлений клубочковим шаром.

Клубочки були розширені, повнонокровні, проте периваскулярний набряк спостерігали лише у тварин із ГПП (рис. 1). Просвіти капсул переважно не містили серозного ексудату. Дрібні судини венозного типу обох шарів нирки були дещо розширені та повнокровні, в окремих полях зору мали місце дрібні периваскулярні крововиливи. У тварин з ГПП на тлі ЦД більшість вивідних канальців були розширені, проте просвіти їх слабо візуалізувались (рис. 2). В петлях Генле і прямих канальцях ми спостерігали виражений набряк епітелію, що різко звужувало їх просвіти. В дистальних канальцях мали місце гідропічна білкова дистрофія, еозинофілія цитоплазми, а також слаб-

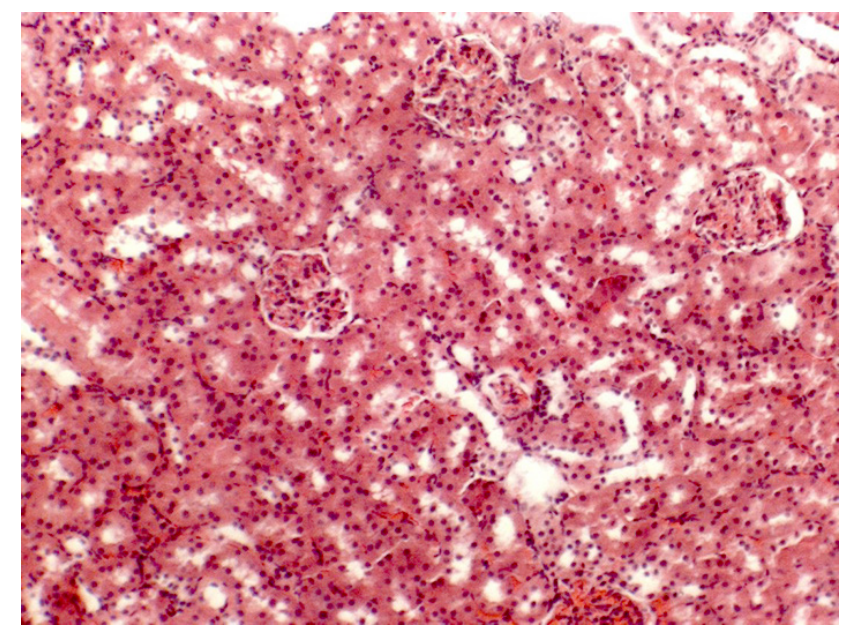

Рис. 1. Гістологічна структура кіркової речовини нирки тварини з ГПП на 1-шу добу експерименту. Забарвлення гематоксиліном та еозином.×200. 


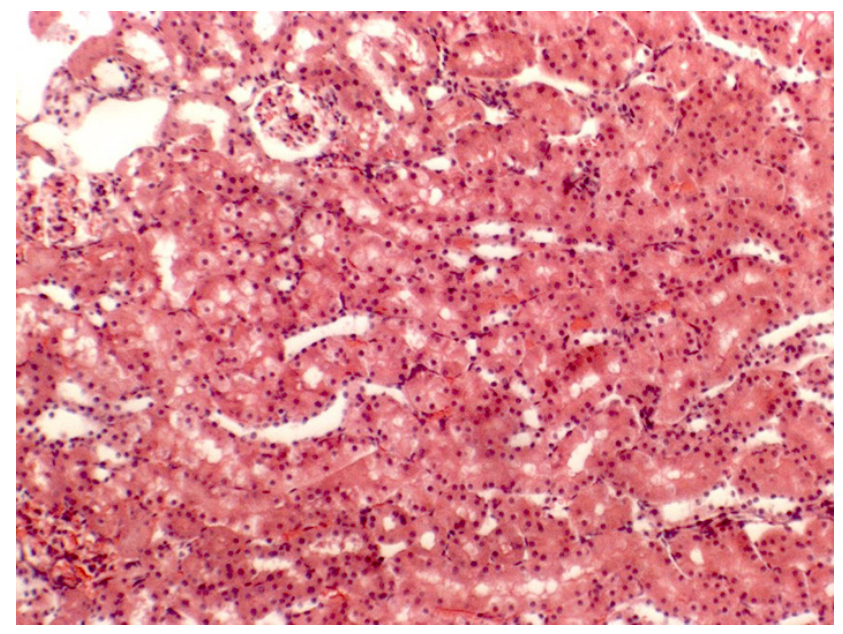

Рис. 2. Гістологічна структура кіркової речовини нирки тварини з ГПП на тлі ЦД на 1-шу добу експерименту. Забарвлення гематоксиліном та еозином. ×200.

кий зв’язок пошкодженого епітелію із базальною мембраною (рис. 3).

В судинах мозкового шару також спостерігали повнокрів'я та незначний периваскулярний набряк, який поєднувався із незначною лімфогістіоцитарною інфільтрацією).

При гістологічному дослідженні тканини нирки тварин з ГПП на 3-тю добу експерименту ми спостерігали, що у кірковому шарі нирки клубочки були дещо розширені, судини їх повнокровними (рис. 4), в просвітах спостерігався серозний та серозно-геморагічний ексудат, окремі клубочки були зморщені, колабовані.

У тварин із ГПП на тлі ЦД судини венозного русла дещо розширювались, були повнокровні, візуалізувались дрібні периваскулярні точкові крововиливи (рис. 5). Більшість вивідних канальців

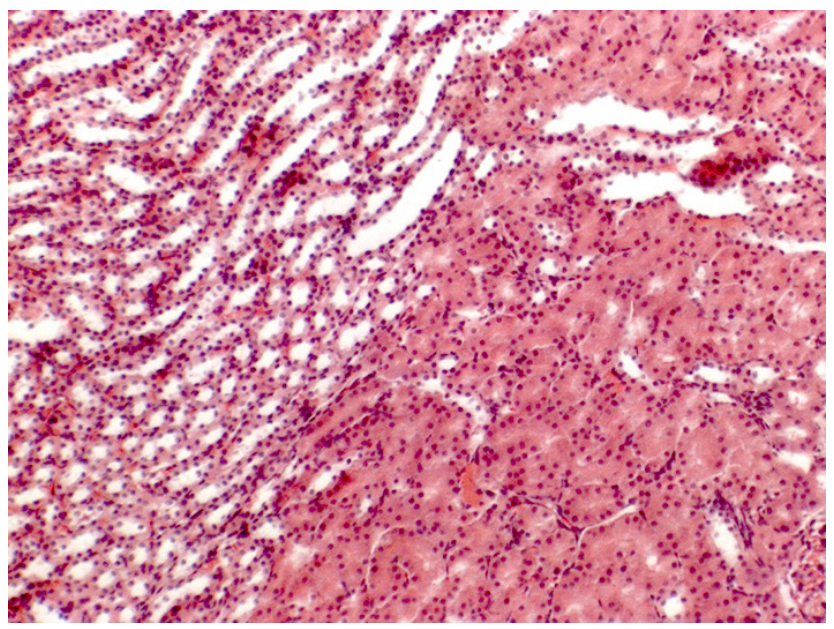

Рис. 3. Гістологічна структура мозкової речовини нирки тварини з ГПП на тлі ЦД на 1-шу добу експерименту. Забарвлення гематоксиліном та еозином.×200.

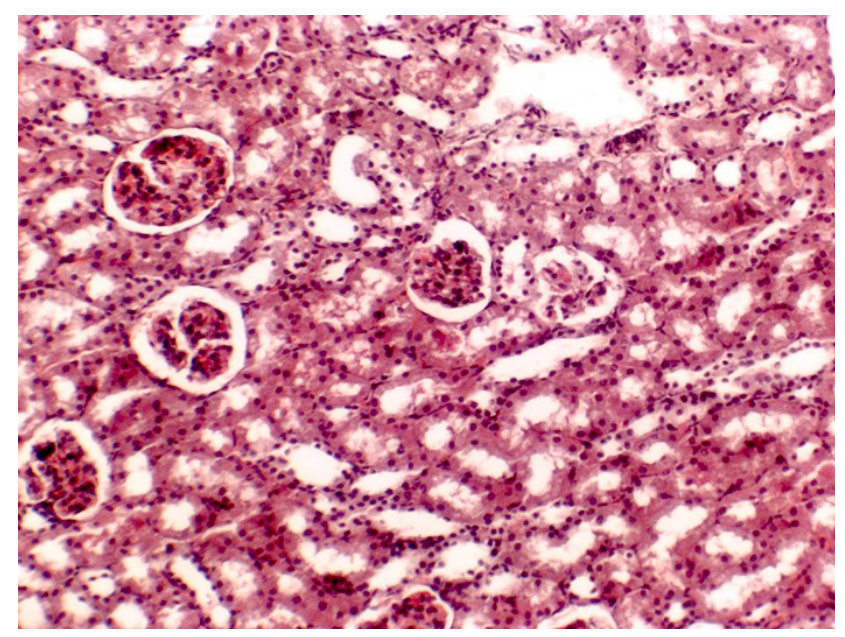

Рис. 4. Гістологічна структура кіркової речовини нирки тварини з ГПП на 3-тю добу експерименту. Забарвлення гематоксиліном та еозином. $\times 200$.

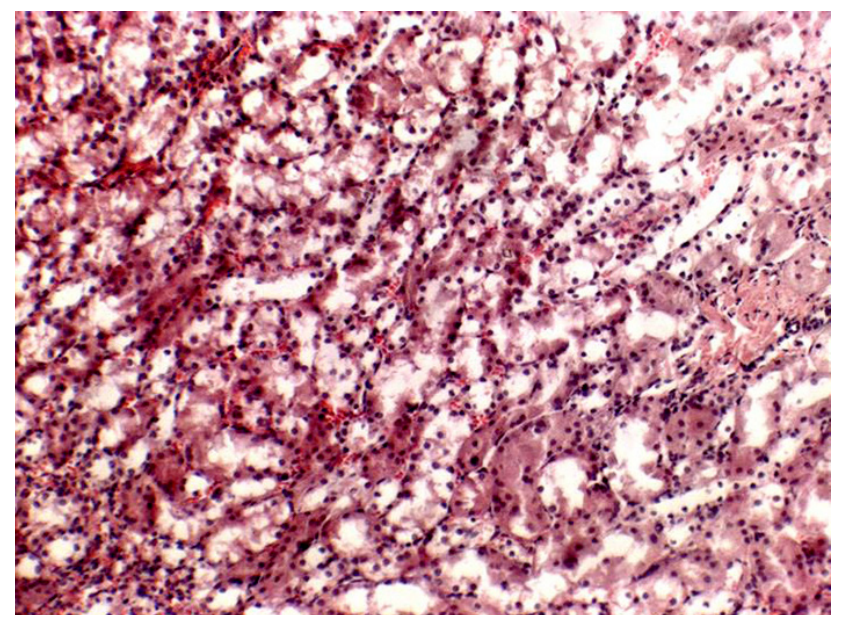

Рис. 5. Гістологічна структура мозкової речовини нирки тварини з ГПП на тлі ЦД на 3-тю добу експерименту. Забарвлення гематоксиліном та еозином.×200.

були розширені, проте просвіти їх були вільні від ексудату. В петлях Генле і прямих канальцях ми спостерігали виражений набряк епітелію.

У дистальних канальцях мали місце гіаліновокраплинна та гідропічна білкова дистрофія, еозинофілія цитоплазми, а також слабкий зв'язок пошкодженого епітелію із базальною мембраною. Велика кількість епітеліоцитів не містили ядер, що свідчить про наявність дистрофічно-некротичних змін (рис. 6). В судинах мозкового шару також спостерігалось повнокрів'я та периваскулярний набряк, який поєднувався із незначною периварискулярною лімфогістіоцитарною інфільтрацією.

При гістологічному дослідженні тканини нирки тварин з ГПП на 7-му добу експерименту ми спостерігали, що у кірковому шарі нирки клубочки були дещо збільшені, розширені, їх судини пов- 


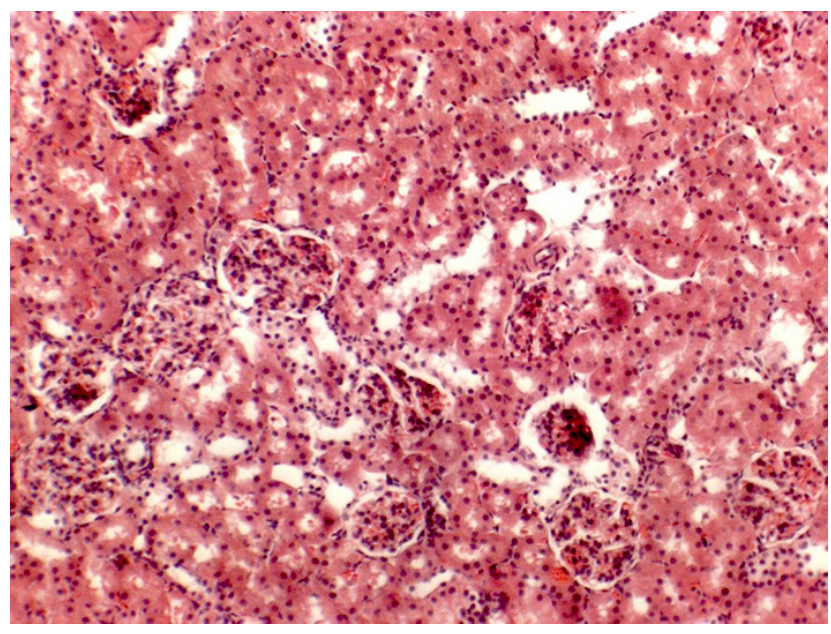

Рис. 6. Гістологічна структура кіркової речовини нирки тварини з ГПП на тлі ЦД на 3-тю добу експерименту. Забарвлення гематоксиліном та еозином.×200.

нокровні (рис. 7), в просвітах спостерігався серозний ексудат, окремі клубочки були зморщені, колабовані.

Судини венозного русла дещо розширювались, були повнокровні, візуалізувались дрібні периваскулярні точкові крововиливи у тварин усіх досліджуваних груп (рис. 7-9).

У тварин з ГПП на тлі ЦД більшість вивідних канальців були розширені, в їх просвітах спостерігався серозний ексудат, а в окремих полях зору виявлялись поодинокі еритроцити (рис. 8). В петлях Генле і прямих канальцях ми спостерігали виражений набряк епітелію.

У дистальних канальцях мали місце виражена гідропічна білкова дистрофія, еозинофілія цитоплазми, а також слабкий зв'язок пошкодженого епітелію із базальною мембраною (рис. 9). Більшість

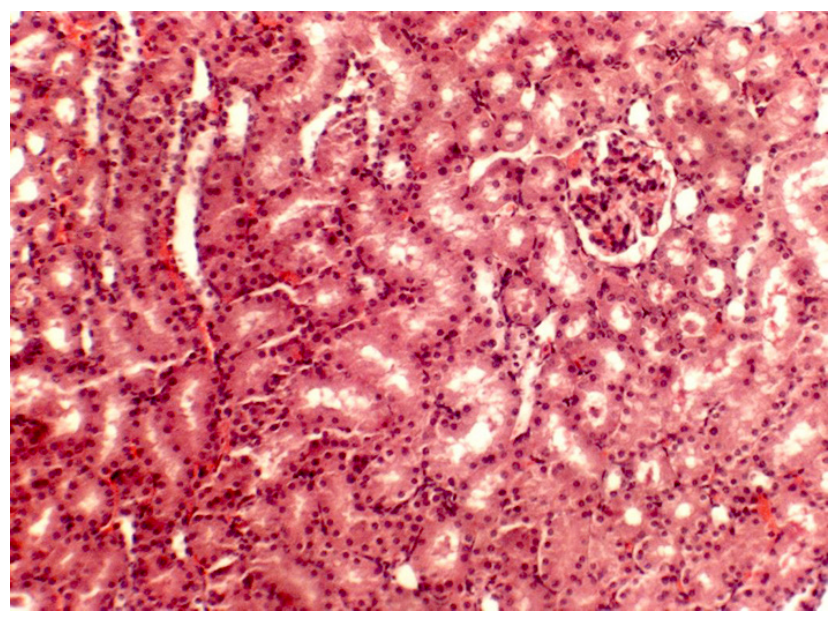

Рис. 7. Гістологічна структура кіркової речовини нирки тварини з ГПП на 7-му добу експерименту. Забарвлення гематоксиліном та еозином. $\times 200$.

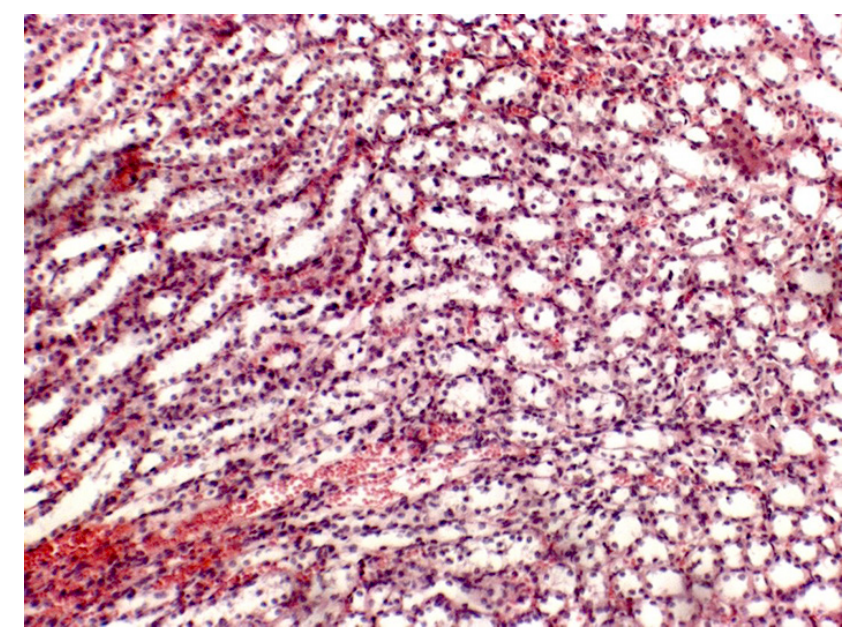

Рис. 8. Гістологічна структура мозкової речовини нирки тварини з ГПП на тлі ЦД на 7-му добу експерименту. Забарвлення гематоксиліном та еозином. $\times 200$.

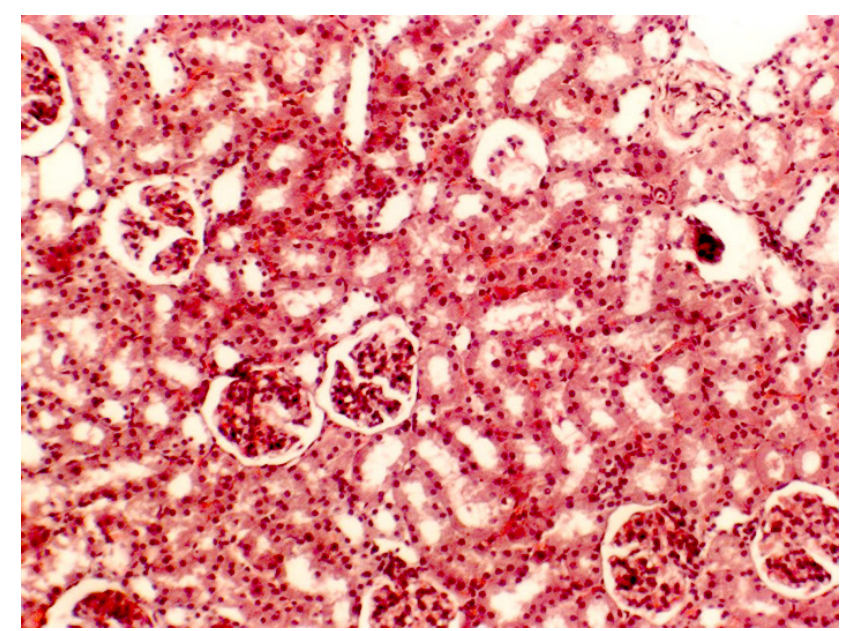

Рис. 9. Гістологічна структура кіркової речовини нирки тварини з ГПП на тлі ЦД на 7-му добу експерименту. Забарвлення гематоксиліном та еозином.×200.

епітеліоцитів містили ядра, розташовані близько базальних мембран. В судинах мозкового шару також спостерігалось повнокрів'я та периваскулярний набряк, який поєднувався із незначною периварискулярною лімфогістіоцитарною інфільтрацією.

Висновки. Отже, у тварин із ГПП на тлі ЦД спостерігалися більш виражені патоморфологічні зміни у тканині нирок порівняно із групою тварин, яким не моделювали ЦД. Зокрема у тварин на першу добу після моделювання ГПП спостерігався лише периваскулярний набряк, просвіти капсул не містили серозного ексудату. У цей термін у тварин із ГПП на тлі ЦД в петлях Генле і прямих канальцях спостерігався виражений набряк епітелію, що різко звужувало їх просвіти. При гістологічному дослідженні тканини нирки тварин з ГПП 


\section{ЕКСПЕРИМЕНТАЛЬНІ ДОСЛІДЖЕННЯ}

на 7-му добу експерименту у кірковому шарі нирки клубочки були дещо збільшеними, розширени-

\section{СПИСОК ЛІТЕРАТУРИ}

1. Росул М. В. Мікробіологічний моніторинг ран у хворих на синдром стопи діабетика на фоні озонотерапії в практиці сімейного лікаря / М. В. Росул, Б. М. Пацкань // Україна. Здоров’я нації. - 2016. - № 1-2. - С. 165-169.

2. Никитюк Л. А. Цукровий діабет, індукований екзогенним введенням глюкокортикостероїдів / Л. А. Никитюк // Міжнародний ендокринологічний журнал. - 2016. - № 8. - С. 17-19. 3. Новые возможности профилактики сахарного диабета 2-го типа / К. А. Зуев, Д. Г. Когут // Міжнародний ендокринологічний журнал. - 2013. - № 6. - С. 29-36.

4. Evert A. B. Recommendations of the American Diabetes Association for Food Therapy in Adult Patients with Diabetes Mellitus / A. B. Evert, J. L. Boucher // Diabetes. Adiposity. Metabolic Syndrome. - 2014. - Vol. 5. - P. 34-46.

5. Полянський I. Ю. Особливості розвитку, перебігу, профілактики та лікування перитоніту при променевому ураженні (експериментально-клінічне дослідження: автореф. дис. на

\section{REFERENCES}

1. Rosul, M.V., \& Patskan, B.M. (2016). Mikrobiolohichnyi monitorynh ran u khvorykh na syndrom stopy diabetyka na foni ozonoterapii v praktytsi simeinoho likaria [Microbiological monitoring of wounds in patients with diabetic foot syndrome on the background of ozonotherapy in the practice of a family doctor]. Ukraina. Zdorovia natsii - Ukraine. Health of Nation, 1-2, 165-169 [in Ukrainian].

2. Nykytiuk, L.A. (2016). Tsukrovyi diabet, indukovanyi ekzohennym vvedenniam hliukokortykosteroidiv [Diabetes mellitus induced by exogenous administration of glucocorticosteroids]. Mizhnarodnyi endokrynolohichnyi zhurnal International Endocrinologic Journal, 8, 17-19 [in Ukrainian]. 3. Zuev, K.A., \& Kogut, D.H. (2013). Novye vozmozhnosti profilaktiky sakharnogo diabeta 2-go tipa [New features of prevention of type 2 diabetes]. Mizhnarodnyi endokrynolohichnyi zhurnal - International Endocrinologic Journal, 6, 29-36 [in Russian].

4. Evert, A.B., \& Boucher, J.L. (2014). Recommendations of the American Diabetes Association for Food Therapy in Adult Patients with Diabetes Mellitus. Diabetes. Adiposity. Metabolic syndrome, 5, 34-46. ми, судини їх повнокровними, в просвітах спостерігався серозний ексудат.

здобуття наук. ступеня докт. мед. наук: спец. - “Хірургія”. Київ, 1996. - 40 с.

6. Data collection methods in health services research: hospital length of stay and discharge destination / M. N. Sarkies, K. A. Bowles, E. H. Skinner [et al.] // Appl. Clin. Inform. - 2015. - Vol. 6. - P. 96-109. 7. Campbell-Scherer D. Multimorbidity: a challenge for evidence-based medicine / D. Campbell-Scherer // Evid. Based Med. - 2010. - Vol. 15 (6). - P. 165-166.

8. Al-Malki A. L. Oat attenuation of hyperglycemia-induced retinal oxidative stress and NF-kkB activation in streptozotocininduced diabetic rats / A. L. Al-Malki // Hindawi Publishing Cjrporation Evidence-Based: Complrmentary and Alternative Medicine. - 2013. - Vol. 45 (2). - P. 116-120.

9. Экспериментальная модель распространенного калового перитонита / В. А. Лазаренко, В. А. Липатов, Ю. Ю. Блинков, Д. В. Скориков // Человек и его здоровье. - 2008. - № 4. - С. 128132.

5. Polianskyi, I.Iu. (1996). Osoblyvosti rozvytku, perebihu, profilaktyky ta likuvannia perytonitu pry promenevomu urazhenni (eksperymentalno-klinichne doslidzhennia) [Peculiarities of development, course, prophylaxis and treatment of peritonitis with radiation injury (experimental-clinical study)]. Doctor's Extended abstract. Kyiv [in Ukrainian].

6. Sarkies, M.N., Bowles, K.A., \& Skinner, E.H. (2015). Data collection methods in health services research: hospital length of stay and discharge destination. Appl. Clin. Inform., 6, 96-109.

7. Campbell-Scherer, D. (2010). Multimorbidity: a challenge for evidence-based medicine. Evid. Based Med., 15 (6), 165-166. 8. Al-Malki, A.L. (2013). Oat attenuation of hyperglycemiainduced retinal oxidative stress and NF-kkB activation in streptozotocin-induced diabetic rats. Hindawi Publishing Cjrporation Evidence-Based: Complrmentary and Alternative Medicine, 45 (2), 116-120.

9. Lazarenko, V.A., Lypatov, V.A., Blynkov, Yu.Yu., \& Skorikov, D.V. (2008). Eksperymentalnaya model rasprostranennogo kalovogo perytonita [Experimental model of general fecal peritonitis]. Chelovek i ego zdorovye - Man and his Health, 4, 128-132 [in Russian]. 
I. YA. DZUBANOVSKY ${ }^{1}$, B. M. VERVEHA², S. R. PIDRUCHNA ${ }^{1}$, N. A. MELNYK ${ }^{1}$

I. Horbachevsky Ternopil State Medical University ${ }^{1}$

Danylo Halytskyi Lviv National Medical University ${ }^{2}$

\title{
MORPHOLOGICAL CHANGES IN KIDNEYS IN CONDITIONS OF ACCUTE PERITONITIS ON THE BACKGROUND OF DIABETES MELLITUS
}

\begin{abstract}
The aim of the work: to investigate the morphological changes in the kidneys of experimental animals in a simulated acute general peritonitis on the background of diabetes mellitus compared to animals with experimental acute peritonitis.

Materials and Methods. 56 white rats were used in this work. Diabetes mellitus was modeled by intraperitoneal injection of streptozotocin by Sigmal brand at a rate of $7 \mathrm{mg}$ per $100 \mathrm{~g}$ of animal weight, acute peritonitis - by administering $0.5 \mathrm{ml}$ of $10 \%$ captured fecal suspension to the abdominal cavity of the animals under study. Investigated kidney tissue 1, 3, 7 days from the beginning of peritonitis modeling.

Results and Discussion. In animals with acute general peritonitis, the pathomorphological changes were more pronounced on the background of diabetes mellitus: the vessels of the venous channel were slightly enlarged, were full-blooded, and visualized small perivascular hemorrhages. The vast majority of the outflow tubules were expanded, but their enlightenment was free of exudates. In the loops of Henle and the direct tubules, we observed a marked edema of the epithelium.
\end{abstract}

Key words: acute general peritonitis; diabetes mellitus; morphological changes in the kidney.

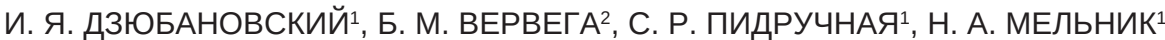

ГВУЗ “Тернопольский государственный медицинский университет имени И. Я. Горбачевского МОЗ Украины” Львовский национальный медицинский университет имени Данила Галицкого ${ }^{2}$

\section{МОРФОЛОГИЧЕСКИЕ ИЗМЕНЕНИЯ В ПОЧКАХ ПРИ УС.ОВИИ ОСТРОГО РАСПРОСТРАНЕННОГО ПЕРИТОНИТА НА ФОНЕ САХАРНОГО ДИАБЕТА}

\begin{abstract}
Цель работы: исследовать морфологические изменения в почках подопытных животных при смоделированном остром распространенном перитоните на фоне сахарного диабета по сравнению с животными с экспериментальным острым распространенным перитонитом.

Материалы и методы. В работе использовали 56 белых крыс. Сахарный диабет моделировали путем внутрибрюшинного введения стрептозотоцина фирмы “Sigmal” из расчета 7 мг на 100 г массы животного, острый распространенный перитонит - введением 0,5 мл 10 \% профильтрированной каловой суспензии в брюшную полость исследуемых животных. Исследовали ткань почки 1, 3, 7 суток от начала моделирования перитонита.

Результаты исследований и их обсуждение. У животных с острым распространенным перитонитом на фоне сахарного диабета патоморфологические изменения были более выраженными: сосуды венозного русла несколько расширялись, были полнокровными, визуализировались мелкие периваскулярные точечные кровоизлияния. Подавляющее большинство выводных канальцев были расширены, однако просвещения их были свободными от экссудата. В петлях Генле и прямых канальцах мы наблюдали выраженный отек эпителия.

У животных с острым распространенным перитонитом на фоне сахарного диабета наблюдались более выраженные патоморфологические изменения в тканях почек во все сроки наблюдения по сравнению с группой животных, которым не моделировали сахарный диабет, что характеризовались периваскулярным отеком, увеличением и расширением сосудистого просвета, наличием серозного экссудата.
\end{abstract}

Ключевые слова: острый распространенный перитонит; сахарный диабет; морфологические изменения почки. 